\title{
Assessment of bacterial carriage on the hands of primary school children in Calabar municipality, Nigeria
}

\author{
Ofonime M. Ogba*, Patience E. Asukwo ${ }^{\dagger}$ and lquo B. Otu-Bassey ${ }^{\dagger}$
}

\begin{abstract}
Background: Hand washing with soap and water is a good hand hygiene practice which reduces the chance of infection transmission through hand contact. This study was designed to determine the microbial hand carriage among nursery and primary school children in Calabar Metropolis and to assess the effect of hand washing in the reduction of bacterial hand carriage among these children.
\end{abstract}

Methods: A total of 150 pupils aged 2-13 years were enrolled in the study from both private and public nursery and primary schools. Ethical approval was obtained from the Cross River State Ministry of Health, before the collection of the samples. Informed consent was obtained from the management of the schools and the parents and guardian of the children. A structured questionnaire was administered to the pupils for information on demography, hand hygiene practice, and their awareness on the importance of hand washing. Hand swabs were obtained from the pupils before and after hand washing respectively. Samples were subjected to culture, microscopy, and biochemical analysis. Data obtained in the study were analyzed by Epi-Info CDC, 2012 package.

Results: Males had the highest occurrence of the isolates 82 (62.1\%) than females 50 (37.8\%). This study recorded 88. $0 \%$ prevalence of bacterial hand carriage among school children. Staphylococcus aureus was the most common isolate (68.9\%) recovered before hand washing followed by Escherichia coli (25.0\%). Proteus vulgaris and Pseudomonas aeruginosa were not found on the pupils' hands after hand washing. There was a significant difference in the bacterial carriage after hand washing between the two soap types $\left(x^{2}=19.9, p=0.001\right)$ with Dettol soap subjects having a lower bacterial carriage (31.2\%) than Tetmosol soap subjects (68.8\%).

Conclusion: The isolated bacteria were potential pathogens in humans. There was a significant reduction in bacterial carriage after hand washing with antibacterial soaps. School children should be educated on the need to wash hands with clean water and soap and dry with clean towels as this will reduce the risk of transmission of pathogenic bacteria orally or into open wounds.

Keywords: Bacterial carriage, Hand hygiene, Children, Soaps

\section{Background}

Hand hygiene has been recognized as an important public health measure, but the use of soap to remove pathogens from hands has not been concluded. Soap usage for hand hygiene has not been unanimously recommended in low-income settings (Ejemot et al., 2008).

\footnotetext{
* Correspondence: ofonimemark@yahoo.com

${ }^{\dagger}$ Equal contributors

Department of Medical Laboratory Science, Faculty of Allied Medical Sciences, University of Calabar, Calabar, Nigeria
}

The primary mode of transmission of many infectious diseases is the hand, especially among people working in close proximity to one another such as in schools. Contaminated hands serve as vehicles of transmission of infectious diseases (Ogba et al., 2016) which may increase infection rates among children. Hand washing is the most effective and simple method of preventing the spread of communicable diseases (Burton et al., 2011).

Lack of compliance to basic hand washing practice in the school environments due to time constraints and lack of water and sinks in most classrooms has been 
reported as a contributor to disease outbreaks by the World Health Organization (World Health Organization guidelines on hand hygiene in health care, 2013).

Infection transmission through contaminated hands of school children is a common pattern seen in most nursery and primary schools. Failure to perform appropriate hand hygiene practice has been recognized as a significant contributor to outbreaks of infectious diseases by the World Health Organization (World Health Organization guidelines on hand hygiene in health care, 2013). This study was designed to determine the microbial hand carriage among nursery and primary school children in Calabar Metropolis and to evaluate the effect of hand washing in the reduction of bacterial hand carriage among these children.

\section{Methods}

\section{Study design/setting}

The study was a prospective cross-sectional study carried out in three primary and nursery schools in Calabar Metropolis of Cross River State, Nigeria.

\section{Study population}

The study population comprised of pupils in both private and public nursery and primary schools, aged $2-11$ years.

\section{Inclusion and exclusion criteria}

Pupils and teachers who did not give consent were excluded from the study while those who gave consent were recruited into the study.

\section{Sample collection}

A structured questionnaire was administered to the Head teacher and children for information on hand hygiene practice and awareness of the importance of hand washing. A total of 300 hand swabs were obtained from all the pupils. One hundred and fifty swabs were obtained before hand washing and 150 after hand washing respectively. Sterile cotton swabs dampened in sterile $0.85 \%$ saline were used to obtain samples from the fingers, between the fingers, and from the palm of the school children (De Alwis et al., 2012). The swab sticks were transported to the Microbiology Laboratory, University of Calabar Teaching Hospital (UCTH), for processing. The samples were transported in an Amies transport medium.

\section{Indicated soaps for the study and product formulation}

The indicated soaps for the study were Dettol and Tetmosol soaps.

\section{Dettol soap}

Dettol is an antiseptic cleaning agent with $4.8 \% w / v$ chloroxylenol as the active ingredient. The other ingredients include isopropyl alcohol, pine oil, castor oil, caramel, and water. These ingredients make Dettol an effective antiseptic-disinfectant that kills bacteria. Chloroxylenol is the antibacterial in Dettol that acts to kill germs and reduce inflammation (Chew, 2015). Chloroxylenol has good activity against gram-positive bacteria but poor activity against gram-negative bacteria, enveloped viruses, mycobacteria, and fungi. It has doubtful activity against non-enveloped viruses and no activity against bacterial spores (Mathur, 2011; Kampf \& Kramer, 2004). Chloroxylenol activity is minimally affected in the presence of organic materials but neutralized by non-ionic surfactants. It is well tolerated when absorbed through the skin (Mathur, 2011; Kampf \& Kramer, 2004).

\section{Tetmosol soap}

Tetmosol soap is an antibacterial and antigermicidal soap. It is composed of monosulfiram $5 \% w / w$ as the active ingredient. The other constituent of Tetmosol is $75 \%$ total fatty matter (TFM). Monosulfiram is active against the skin mite Sarcoptes scabei which causes scabies (Piramal Healthcare, 2016).

\section{Training for hand washing}

The training of hand washing was conducted before the experiment. It was carried out according to $\mathrm{WHO}$ guidelines (Guide to implementation of the WHO multimodal hand hygiene improvement strategy, 2010; WHO Guidelines on Hand Hygiene in Health Care, 2010). All the pupils enrolled in the study and the teachers that washed the younger pupils were trained 2 days before the sample collection.

\section{Grouping method for the two soaps}

The random assignment principle was followed for grouping the school children between the two soap types provided for them to wash hands. Dettol and Tetmosol were printed on paper, wrapped, and put in a basket for them to pick. Whatever soap the pupils picked was provided for them to wash with. Out of the 150 subjects enrolled in the study, 75 (50.0\%) washed with Dettol while the other 75 (50.0\%) washed with Tetmosol. Out of the 85 female children, 43 (50.6\%) washed with Dettol soap while $42(49.4 \%)$ washed with Tetmosol soap. A total of 65 male subjects were enrolled in the study, 32 (49.2\%) washed with Dettol soap while 33 (50.8\%) washed with Tetmosol soap.

\section{Pre-wash and hand washing procedure}

The procedure is done as follows: Remove jewelries and rinse hands under running water. Lather with soap and using friction, cover all surfaces of hands and fingers. Rub your left hand's dorsum with your 
Table 1 The demography of subjects in selected schools

\begin{tabular}{llll}
\hline & $\begin{array}{l}\text { Females } \\
\text { No. (\%) enrolled }\end{array}$ & $\begin{array}{l}\text { Males } \\
\text { No. (\%) enrolled }\end{array}$ & Total \\
\hline Age (years) & & & \\
$2-4$ & $15(17.6)$ & $10(15.4)$ & $25(16.7)$ \\
$5-7$ & $35(41.2)$ & $28(43.1)$ & $63(42.0)$ \\
$8-10$ & $20(23.5)$ & $17(26.2)$ & $37(24.7)$ \\
11 and above & $15(17.7)$ & $10(15.4)$ & $25(16.7)$ \\
Total & $85(56.7)$ & $65(43.3)$ & 150 \\
Class in school & & & \\
Nursery & $15(17.7)$ & $10(15.4)$ & $25(16.7)$ \\
Primary & $70(82.4)$ & $55(84.6)$ & $125(83.3)$ \\
\hline
\end{tabular}

right hand and your right hand's dorsum with the left hand. Rub your palms and clean your fingers. Clean hand dorsa by rubbing them to your palms. Rub your two thumbs with your other hand. Clean finger tips, rinse hands with water, and dry with disposable paper towel. The paper towel is used to turn off the faucet and trashed after the process without touching the trash (Cevizci et al., 2015).

\section{Culture}

The samples collected were cultured on chocolate agar, cysteine lactose electrolyte-deficient (CLED) agar, and blood agar. Plates were incubated at $37{ }^{\circ} \mathrm{C}$ in a canister with $5-10 \% \mathrm{CO}_{2}$ but CLED were incubated aerobically at $37^{\circ} \mathrm{C}$ respectively for $24-48 \mathrm{~h}$.

\section{Identification of isolates}

Plates were examined for growth and isolates were identified morphologically, physiologically, and biochemically. The tests carried out on the isolates include gram staining technique, oxidase test, coagulase test, catalase test, urease test, indole test, motility, citrate test, and sugar fermentation tests.

\section{Statistical analysis}

Data were analyzed using Epi Info 2010 (CDC, Atlanta, Georgia, USA) statistical software. Descriptive statistics were carried out. Frequencies were calculated for categorical variables. Interactions between specific categorical clinical variables were tested for significance using the $\chi^{2}$ test. A $p$ value of $\leq 0.05$ was considered statistically significant.

\section{Results}

Table 1 shows the demography of the subjects. Out of 150 pupils enrolled in the study, 85 (56.7\%) were females while $65(43.3 \%)$ were males with a mean age of $7.17 \pm 2.73$. The mean age for females was $6.7 \pm 2.9$, while the mean age for boys was $7.6 \pm 2.2$. The minimum age among the subjects was 2.0 years while the maximum age was 13 years. Subjects were aged 2-13 years. Most of the subjects enrolled (42.0\%) were aged 5-7 years. More pupils were also enrolled from the primary sections $125(83.3 \%)$ than from the nursery classes 25 (16.7\%).

Figure 1 shows the different reasons for hand washing as given by the school children. Most of the pupils (45.3\%) responded that they washed hands to remove germs and dirt, while others (38.6\%) said the exercise was to keep their hands clean. Only $16.0 \%$ said it was to avoid infection from germs.

Figure 2 shows the water availability in schools for hand hygiene practice. Most of the pupils (52.0\%) responded that they were provided a tap with running water for washing hands after playing and using toilets in the school and $32.6 \%$ said they had sinks in their classroom with running water, while $15.3 \%$ said a basin of water was provided in the class for hand washing

Out of the 150 pupils enrolled in the study, 67 (33.1\%) said hand washing does not take a long time while 83 (66.9\%) said it was time wasting. Also, 105 (70.0\%) said they felt dirty after using the toilet but only 94 (62.7\%) remember to wash their hands after using the toilet. Of the 150 pupils, only 48 (32.0\%) washed hands after playing in the school (Table 2).

Figure 3 shows the distribution of bacterial isolates among subjects by gender. Males had the highest occurrence of the isolates $82(62.1 \%)$ than females 50 (37.8\%).

Table 3 shows the bacterial hand carriage by age of subjects. Those aged 5-7 years had the highest bacterial carriage rate $52(39.4 \%)$ followed by those aged
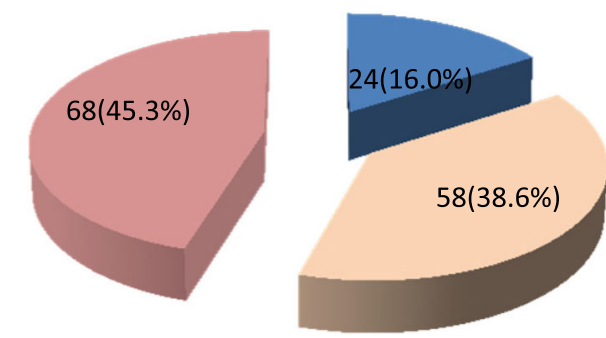

TO AVOID INFECTION WITH GERMS

TO KEEP IT CLEAN

TO REMOVE GERMS AND

DIRTS

Fig. 1 Reasons for hand washing by school children 


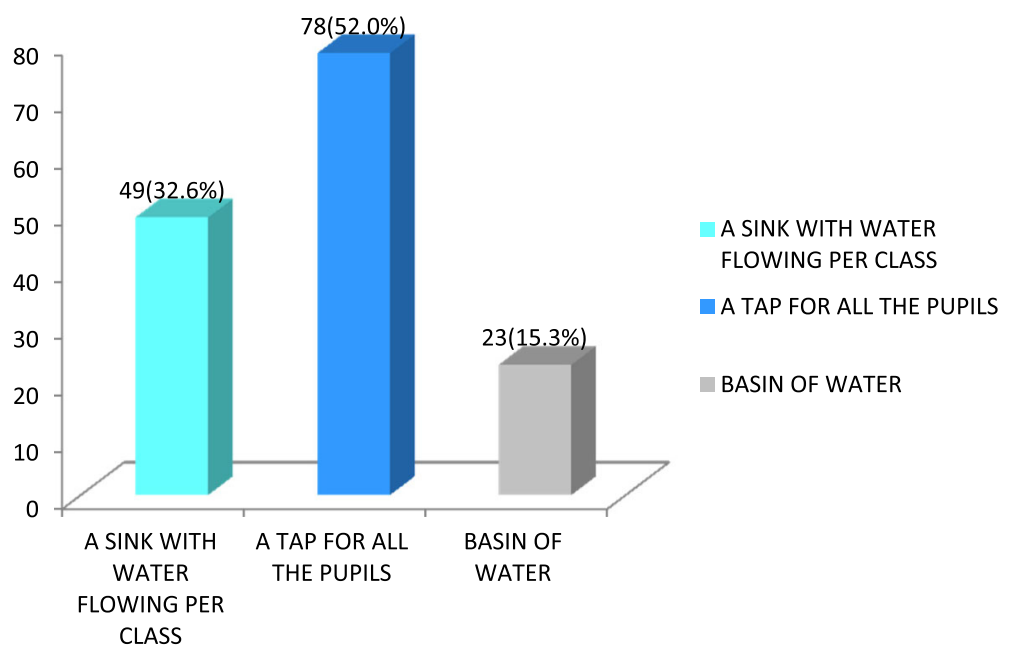

Fig. 2 Water availability for hand washing in schools

8-10 years 41 (31.1\%). The lowest bacterial carriage rate $13(9.9 \%)$ was recorded among children aged 11 years and above.

Table 4 shows the distribution of bacterial isolates before and after hand washing among pupils by soap types. More isolates were recovered from the subjects before hand washing $132(88.0 \%)$ than after hand washing 32 (21.3\%). Staphylococcus aureus was the most common isolate $(68.9 \%)$ recovered before hand washing followed by Escherichia coli (25.0\%). Staphylococcus aureus was also the most common isolate $(81.3 \%)$ recovered after hand washing followed by E. coli (18.7\%). Proteus vulgaris and Pseudomonas aeruginosa were not found on the pupils' hands after hand washing.

Out of the 150 pupils enrolled in the study, 75 washed with Tetmosol and the other 75 washed with Dettol soap respectively. Isolate recovery from subjects that washed hands with Tetmosol was higher $22(68.8 \%)$ than those that washed with Dettol soap 10 (31.2\%). Staphylococcus aureus was the highest recovered isolate 26 (81.3\%) from both soaps, followed by E. coli 6 (18.8\%). Pseudomonas aeruginosa and $P$. vulgaris were not recovered after hand washing. There was a significant difference in the bacterial carriage after hand washing between the two soap types $\left(\chi^{2}=19.9, p=0.001\right)$ with Dettol soap subjects having a lower bacterial carriage 10 (31.2\%) than Tetmosol soap subjects $22(68.8 \%)$ (Table 4$)$.

\section{Discussion}

The challenges of hand hygiene practice in the school environment include time constraints, lack of sinks in most classrooms, and inadequate supply of pipe-borne water or clean water.

This study recorded a prevalence of $88.0 \%$ bacterial hand carriage among school children before hand washing and $21.3 \%$ after hand washing. The $88.0 \%$ carriage before hand washing is higher than the $81.0 \%$ reported by Vivas et al. (2010) while the carriage after hand washing in this study is lower than the $29.0 \%$ reported by Vivas et al. (2010). Despite the campaign of hand hygiene practice in schools after the Ebola outbreak in Nigeria, bacterial hand carriage among pupils was still high (88.0\%). This may be due to lack of availability of water and soap in designated areas in the school premises. Some of the schools provided one washing point for the entire school. The pupils become discouraged because of the crowd at the washing point.

Table 2 Distribution of pupils by their hand hygiene habits

\begin{tabular}{lll}
\hline Hand hygiene habits & No. (\%) of respondents \\
\cline { 2 - 3 } & Yes & No \\
\hline Does washing hands with water take a long time? & $67(33.1)$ & $83(66.9)$ \\
Do you feel dirty if you do not wash hands after using the toilet? & $105(70)$ & 45(30) \\
Do you always remember to wash hands with soap and water after using the toilet? & $94(62.7)$ & 48 (32.0) \\
Do you wash hands after playing? & 102(68.0) \\
\hline
\end{tabular}




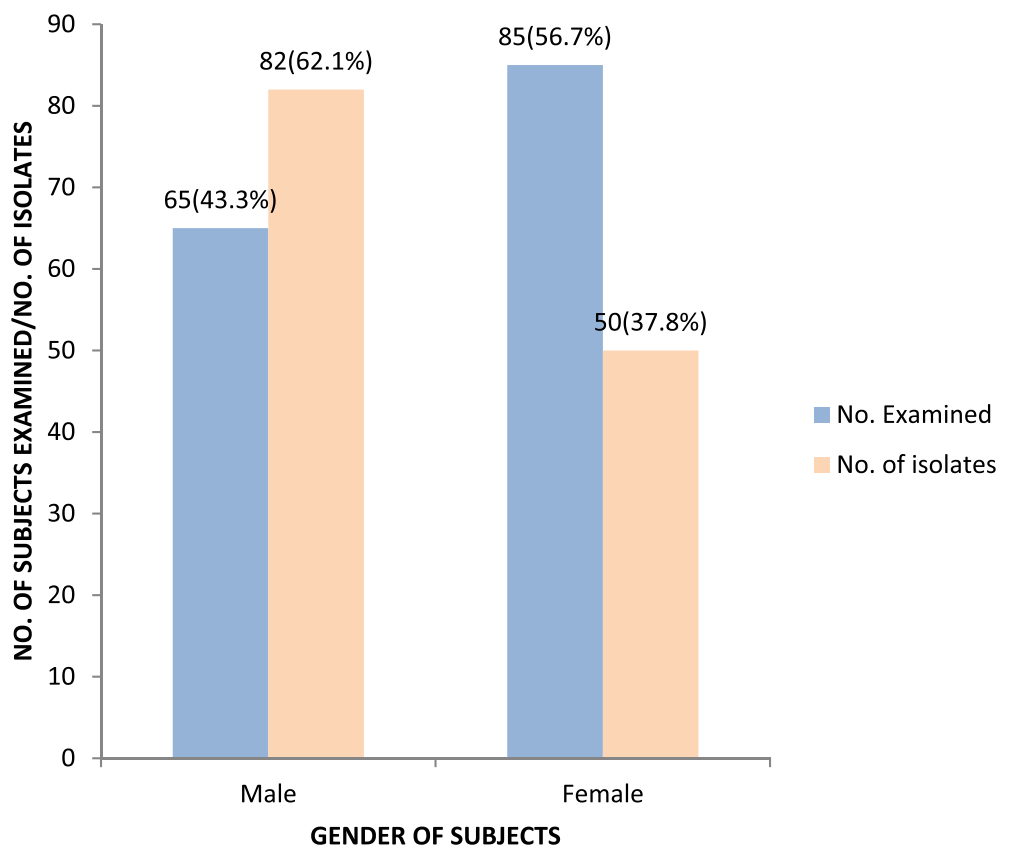

Fig. 3 Distribution of isolates among subjects by gender

The lower recovery rate of $21.3 \%$ after hand washing with the provided soap and water compared to the $29.0 \%$ reported by Vivas et al. (2010) points to the fact that the medicated soaps provided may have substantially reduced the bacterial load compared to the toilet soap provided by Vivas et al. (2010).

Although more females 85 (56.7\%) were recruited than males $65(43.3 \%)$ in the study, most of the isolates 82 $(62.1 \%)$ were recovered from males. This is in agreement with the report of Cruz et al. (2015) that females had a higher knowledge and positive attitude towards hand hygiene than males.

Subjects aged 5-7 years had the highest carriage rate (39.3\%) followed by subjects aged 8-10 years (31.1\%). This may be due to the fact that majority of the subjects were in this age group 93 (70.4\%). However, a recovery rate of $19.7 \%$ was recorded for 25 pupils aged 2-4 years. This was rather surprising because the younger pupils who crawl and play on the floor should pick up more bacteria on their hands but the reverse was the case. The bacterial contamination may have been minimal among this group because their teachers and care givers clean them up after using the toilet, thus minimizing fecal contamination on their hands compared to the older children who are not given such attention. The floor on which they play may have been washed with disinfectant frequently thus minimizing the rate of contamination in this group.

All the bacteria isolated from our subjects were potential pathogens in humans. Staphylococcus aureus 91 (68.9\%) was the most isolated bacteria before hand washing. Chen et al. (2011) reported that children are at a higher risk of colonization by $S$. aureus. Also, S. aureus and $E$. coli were the only recovered isolates after hand washing with the medicated soaps. Although the effect of the soaps on the isolates was not investigated, $P$. vulgaris and $P$. aeruginosa were not found on the pupils' hands after hand washing. This reveals the susceptibility of the two isolates to the medicated soaps. The soaps may have killed or inhibited their growth therefore preventing their recovery.

Table 3 Bacterial hand carriage before hand washing by age of pupils

\begin{tabular}{|c|c|c|c|c|c|c|}
\hline \multirow{2}{*}{$\begin{array}{l}\text { Age } \\
\text { (years) }\end{array}$} & \multirow{2}{*}{$\begin{array}{l}\text { No. } \\
\text { examined }\end{array}$} & \multicolumn{5}{|l|}{ No. (\%) of isolates } \\
\hline & & Staphylococcus aureus & Escherichia coli & Pseudomonas aeruginosa & Proteus vulgaris & Total \\
\hline $2-4$ & 25 & $17(18.7)$ & $9(27.2)$ & $0(0.0)$ & $0(0.0)$ & $26(19.7)$ \\
\hline $5-7$ & 65 & $37(40.7)$ & 11(33.3) & $3(60.0)$ & $1(33.3)$ & $52(39.3)$ \\
\hline $8-10$ & 45 & 28(30.7) & $9(27.2)$ & $2(40.0)$ & $2(66.7)$ & $41(31.1)$ \\
\hline$\geq 11$ & 15 & $9(9.9)$ & $4(12.1)$ & $0(0.0)$ & $0(0.0)$ & 13(9.9) \\
\hline Total & 150 & $91(68.9)$ & $33(25.0)$ & $5(3.8)$ & $3(2.3)$ & 132 \\
\hline
\end{tabular}


Table 4 Bacterial hand carriage before and after hand washing by types of soap

\begin{tabular}{|c|c|c|c|c|}
\hline & \multicolumn{2}{|c|}{ Types of soap/no. (\%) of isolates } & \multirow[t]{2}{*}{ Total } & \multirow[b]{2}{*}{ Statistics } \\
\hline & Tetmosol $(n=75)$ & Dettol soap $(n=75)$ & & \\
\hline \multicolumn{5}{|c|}{ Bacterial isolates present before hand washing } \\
\hline Staphylococcus aureus & $42(46.1)$ & 49(53.9) & $91(68.9)$ & \multirow[t]{5}{*}{$x^{2}=8.6 p=0.07$} \\
\hline Escherichia coli & 13(39.3) & $20(60.0)$ & $33(25.0)$ & \\
\hline Pseudomonas aeruginosa & $4(80.0)$ & $1(20.0)$ & $5(3.7)$ & \\
\hline Proteus vulgaris & $0(0.0)$ & $3(100)$ & $3(2.3)$ & \\
\hline Total & $59(44.7)$ & 73(55.3) & 132(88.0) & \\
\hline \multicolumn{5}{|c|}{ Bacterial isolates present after hand washing } \\
\hline Staphylococcus aureus & $17(77.3)$ & $9(90.0)$ & 26(81.3) & \multirow{5}{*}{$\begin{array}{l}x^{2}=19.9 \\
p=0.001\end{array}$} \\
\hline Escherichia coli & $5(22.7)$ & $1(10.0)$ & $6(18.7)$ & \\
\hline Pseudomonas aeruginosa & $0(0.0)$ & $0(0.0)$ & $0(0.0)$ & \\
\hline Proteus vulgaris & $0(0.0)$ & $0(0.0)$ & $0(0.0)$ & \\
\hline Total & $22(68.8)$ & 10(31.2) & 32 & \\
\hline
\end{tabular}

$n$ number of subjects examined

Although there was a higher bacterial carriage (55.3\%) among subjects grouped to washed with Dettol soap than their Tetmosol soap counterparts (44.7\%) before hand washing, there was a significant difference in the bacterial carriage after hand washing between the two soap types $\left(\chi^{2}=19.9, p=0.001\right)$ with Dettol soap subjects having a lower bacterial carriage (31.2\%) than Tetmosol soap subjects $(68.8 \%)$. This is in agreement with the work of Feroze et al. (2014) who reported that Dettol soap has inhibitory effects against $E$. coli, $S$. aureus, and $P$. aeruginosa. In a similar work, Nwambete and Lyombe (2011) reported that Dettol and Tetmosol had inhibitory activities against $E$. coli and $S$. aureus.

The antibacterial soaps used in the study showed significant reduction in bacterial hand carriage which may have resulted from inhibition of bacterial growth alongside the transient removal of these organisms. These may lead to acquisition of resistance genes by the organism. Burton et al. (2011) in London, UK, reported that hand washing with plain non-bacterial soap resulted in a significant reduction in bacterial hand carriage. In this study, the antibacterial soaps gave more significant results as some of the isolates were completely eliminated. However, toilet soap was not tested in this study because of limitation of funds; this may be better for hand washing in children in order to prevent resistance to the active ingredients and skin irritation.

\section{Conclusion}

The study recorded bacterial hand carriage rates of 88.0 and $21.3 \%$ before and after hand washing respectively. The isolated bacteria were potential pathogens in humans. There was a significant reduction in bacterial carriage after hand washing with antibacterial soaps.
Acknowledgements

We acknowledge Mr. Ben Solomon of the University of Calabar Teaching Hospital for his assistance with the sample analysis. We also acknowledge the University of Calabar for creating an enabling environment for research.

Funding

None.

Availability of data and materials

The dataset(s) supporting the conclusions of this article are included within the article.

\section{Authors' contributions}

OO conceived the study; PE and IO contributed to the design of the study; $\mathrm{OO}$ and PE performed the laboratory studies. All authors analyzed the data drafted the manuscript, and read and approved the final version. $O O$ is the guarantor of the paper.

\section{Ethics approval and consent to participate}

Ethical approval was obtained from the Cross River State Ministry of Health before collection of the samples. Informed consent was obtained from the school proprietor, the head teacher, and pupils in the selected schools.

Consent for publication

Not applicable

\section{Competing interests}

The authors declare that they have no competing interests.

\section{Publisher's Note}

Springer Nature remains neutral with regard to jurisdictional claims in published maps and institutional affiliations.

Received: 7 July 2017 Accepted: 19 December 2017

Published online: 10 February 2018

\section{References}

Burton M, Cobb E, Donachie P, Judah G, Curtis V, Schmidt WP. The effect of Handwashing with water or soap on bacterial contamination of hands. Int J Environ Res Public Health. 2011;8:97-104. https://doi.org/10.3390/ ijerph8010097.

Cevizci S, Uludag A, Topaloglu N, Babaoglu UT, Celik M, Bakar C. Developing students' hand hygiene behaviors in a primary school from Turkey: a schoolbased health education study. Int J Med Sci Public Health. 2015;4:155-61. 
Chen YC, Sheng WH, Wang JT, Chang SC, Lin HC, Tien KL. Effectiveness and limitations of hand hygiene promotion on decreasing healthcare-associated infections. PLoS One. 2011;6(11):e27163.

Chew, N. (2015). Dettol antiseptic ingredients. http://wwwlivestrongcom/article/ 166094-dettol-antiseptic-ingredients/ Last Updated: 23 Apr 2015.

Cruz JP, Cruz CP, Al-Otaibi ASD. Gender differences in hand hygiene among Saudi nursing students. Int I Infect Control. 2015;11(4):1-13.

De Alwis WR, Pakirisamy P, San LW, Xiaofen EC. A study on hand contamination and HandWashing practices amongMedical students. Int Sch Res Network. 2012;2012:Article ID 251483, 5 pages. https://doi.org/10.5402/2012/251483.

Ejemot RI, Ehiri JE, Meremikwu MM, Critchley JA. Hand washing for preventing diarrhoea. Cochrane Database Syst Rev. 2008;1 https://doi.org/10.1002/ 14651858.

Feroze, K., Elsayed, A and Tarek, T. A (2014) Antimicrobial activity of commercial "antibacterial" handwashes and soaps. Indian Dermatol Online J 5 (3): 344346.

Guide to implementation of the WHO multimodal hand hygiene improvement strategy. [accessed on 24 Aug 2010]. Available from: http://www.who.int/ patientsafety/en/

Kampf G, Kramer A. Epidemiologic background of hand hygiene and evaluation of the most important agents for scrubs and rubs. Clin Microbiol Rev. 2004; 17:863-93.

Mathur P. Hand hygiene: back to the basics of infection control. Indian J Med Res. 2011;134(5):611-20. https://doi.org/10.4103/0971-5916.90985.

Nwambete KD, Lyombe F. Antimicrobial activity of medicated soaps commonly used by dares Salam residents in Tanzania. Indian J Pharm Sci. 2011;73(1):92-8

Ogba OM, Selekeowei T, Otu-Bassey I. Infection transmission potential of reusable phlebotomy tourniquet in selected health facilities in Calabar, Nigeria. Eur J Pharm Med Res. 2016;3(10):96-100.

Piramal Healthcare (2016). https://www.indiamart.com/proddetail/tetmosol10568848912.html

Vivas AP, Gelaye B, Aboset N, Kumie A, Berhane Y, Williams MA. Knowledge, attitude and practice of hand hygiene among school children in Angolela. Ethiopia J Prev Med Hygiene. 2010;51:73-9.

WHO Guidelines on Hand Hygiene in Health Care. First Global Patient Safety Challenge. Clean Care is Safer Care. Accessed on 24 Aug 2010]. Available from: http://www.who.int/patientsafety/en/

World health organization guidelines on hand hygiene in health care. Hand washing: step procedure and benefits. Geneva: WHO; 2013.

\section{Submit your next manuscript to BioMed Central and we will help you at every step:}

- We accept pre-submission inquiries

- Our selector tool helps you to find the most relevant journal

- We provide round the clock customer support

- Convenient online submission

- Thorough peer review

- Inclusion in PubMed and all major indexing services

- Maximum visibility for your research

Submit your manuscript at www.biomedcentral.com/submit

) Biomed Central 